TITLE:

\title{
Notes on Japanese Ahermatypic Corals -II New Species of Dendrophyllia
}

$\operatorname{AUTHOR}(\mathrm{S}):$

Ogawa, Kazunari; Takahashi, Kounosuke

\section{CITATION:}

Ogawa, Kazunari ...[et al]. Notes on Japanese Ahermatypic Corals -II New Species of Dendrophyllia. PUBLICATIONS OF THE SETO MARINE BIOLOGICAL LABORATORY 2000, 39(1): 9-16

ISSUE DATE:

2000-12-25

URL:

http://hdl.handle.net/2433/176294

RIGHT: 
Publ. Seto Mar. Biol. Lab., 39 (1): 9 - 16, 2000

\author{
Notes on Japanese Ahermatypic Corals - II \\ New Species of Dendrophyllia \\ KAZUNARI OGAWA ${ }^{1)}$ and KOUNOSUKE TAKAHASHI ${ }^{2)}$ \\ ${ }^{1)}$ Z. Nakai Laboratory, Minami 2-24-23, Koenji, Suginami-ku, Tokyo 166-0003, Japan \\ ${ }^{2)}$ Tokyo Metropolitan Bay Fisheries Environmental Improvement Public Corporation, \\ Konan 4-7-8, Minato-ku, Tokyo 108-0075, Japan
}

\begin{abstract}
Four new species of Dendrophyllia are described and figured. D. suprarbuscula n.sp. was found at $90 \mathrm{~m}$, off Izu Hachijou Island, and $D$. paragracilis n. sp. in the shallow marine cave of Ogasawara Islands and Ryukyu Islands. Other two new species, $D$. futojiku $\mathrm{n}$. $\mathrm{sp}$. having big columellae and D. minima $\mathrm{n}$. sp. having the smallest corallites, were found in shallow waters of Izu Hachijou Island. We revised the key to 20 species of Dendrophyllia and related genera in Japan including new species.
\end{abstract}

Key words: ahermatypic coral, new species, Dendrophyllia, key, Japan

\title{
Introduction
}

In this second report (first report: Ogawa et al., 1997) we introduce four undescribed species of Dendrophyllia from Japan. Two are distinguished from hitherto known species by the septal arrangements, another one has developed columellae, and the remaining one forms very small colonies and has small calices. These species were collected along the Pacific coasts, e.g. Izu Hachijou Island, Ogasawara Islands and Ryukyu Islands, during last 30 years. Corallite morphology was measured directly with vernier calipers. Septa were counted and measured using a binocular microscope with an eyepiece micrometer.

\section{Suborder Dendrophylliina \\ Family Dendrophylliidae \\ Dendrophyllia Blainville, 1830}

Dendrophyllia suprarbuscula n. sp.

(Japanese name: Naga-juji-kisango, new)

(Plate I, Fig. 1; Plate III, Fig. 1)

Material examined

Holotype: Five colony fragments, erect straight corallites, broken basally consisting of 17 corallites.

Paratype: Remaining colony fragments consisting of 27 corallites from the holotype. Original whole colony has dome shape about $20 \mathrm{~cm}$ diameter as shown Plate III when dredged, collected on 17 October, 1980 , by K. Takahashi using a gill net at $90 \mathrm{~m}$ depth, off Izu Hachijou Island, Tokyo, Japan. The holotype is deposited in the National Science Museum, Tokyo (NSMT- Co 1001), the paratype in the Takahashi collection.

Reference specimens: $D$. arbuscula, collected from Toyama Bay, Sea of Japan by N. Horii. 
D. arbuscula, newly collected from Wakayama Prefecture and Tokyo Bay.

Description of holotype

Ten mature corallites of broken basal parts averaging $60.3 \mathrm{~mm}$ height (range: 40.6-82.3). Corallites bud at irregular intervals, branched only once or twice, usually one branch, but only one case of three branches opposite direction occurred. Budding takes place near the calicular margin. Corallite robust, costae flat and $0.5 \mathrm{~mm}$ width with two or three small spinous rows, epitheca undeveloped (Plate I, Fig. 1). Coenenchyme deep red to orange (Plate III, Fig.1).

Septa hexamerally arranged in 4 cycles, S5 occurred dorso-ventral and rarely lateral side. Corallites relatively large and oval, 10 mature corallites averaging $8.2 \mathrm{~mm}$ (range: $6.3-9.8$ ) $\times$ $9.1 \mathrm{~mm}(6.7-11.0)$ in calicular diameter and $3.6 \mathrm{~mm}(3.0-4.0)$ in fossal depth. Each pair of S4 fused together before their enclosed S3, arranging Simple Pourtalès plan (Ogawa and Takahashi, 1995). At the dorso-ventral, a pair of S5 inserted and arranging Duplicate Pourtalès plan (Ogawa and Takahashi, 1995). Columella well developed, consisting of swirled elements tightly fused together. S1 exert, $0.7-1.1 \mathrm{~mm}, \mathrm{~S} 2$ slightly exert, $0.6-0.7 \mathrm{~mm}$ and $\mathrm{S} 3$ less than $0.4 \mathrm{~mm}$.

\section{Etymology}

The specific name suprarbuscula is a combination of prefix supra, meaning "over" in Latin, and the specific name of Dendrophyllia arbuscula Van der Horst, 1922 to which the new species is very similar.

\section{Remarks}

Unfortunately, dredged colonies were broken and we could obtain only remains as holotype and paratypes. As shown on Plate III, the whole colony is very similar to Duncanopsammia, but clearly differ from it in having no corallites united basally by coenosteum. Septal arrangement is very similar to Dendrophyllia arbuscula, which has Simple Pourtalès plan and rarely found Duplicate Pourtalès plan dorsally. On the contrary, this new species has robust and longer corallites than $D$. arbuscula, and has a Duplicate Pourtalès plan at the dorso-ventrally without exception.

\section{Dendrophyllia paragracilis n. sp.}

(Japanese name: Ayatori-kisango, new)

(Plate I, Fig. 2; Plate III, Fig. 2)

Material examined

Holotype: Colony width $7.2 \mathrm{~cm}$, height $8.0 \mathrm{~cm}$, consisting of 10 matured corallites with 6 young corallites collected on 5 November, 1995, by H. Tachikawa at $1 \mathrm{~m}$ depth marine cave using SCUBA at Ogasawara Islands, Tokyo. The holotype is deposited in the Coastal Branch of Natural History Museum and Institute, Chiba (CMNH-ZG0310).

Paratype: Colony width $8.4 \mathrm{~cm}$, height $8.2 \mathrm{~cm}$, consisting of 8 matured corallites with 19 young corallites, collected on 31 January, 1975, by T. Fukuda from 3 to $10 \mathrm{~m}$ depth at Urabishi, off Kuroshima, Ryukyu Islands. It is deposited in the Kushimoto Marine Park Center, Wakayama Prefecture (K.M.P.C., label No.C-56).

Additional specimen: Colony width $8.0 \mathrm{~cm}$, height $12.0 \mathrm{~cm}$, collected on 25 January, 1988, by F. Iwase from $5 \mathrm{~m}$ at Urabishi, off Kuroshima, Ryukyu Islands. It is also deposited in the 
K.M.P.C. (label No.88-69).

Reference specimens: Twenty-two specimens of Dendrophyllia gracilis, newly collected from Izu Hachijou Island, Izu Ohshima Island, Tokyo and Muroto-misaki, Kochi Prefecture, Shikoku.

Description of holotype

Corallum dendroid, sparsely branching in three dimensions. The height of 8 mature corallites $26.8-59.6 \mathrm{~mm}$. Young corallites augmented by settlement of sexually produced planulae on the coenosteum. Corallite thin, costae very fine, $0.02 \mathrm{~mm}$ width with a row of blunt spicules (Plate I, Fig. 2). Coenenchyme orange (Plate III, Fig. 2).

Septa hexamerally arranged in 4 complete cycles, S5 ambiguous when present. Corallites medium size, almost circulae, 8 mature corallites averaging $7.9 \mathrm{~mm}$ (range: $6.7-8.8$ ) $\times 8.1$ $\mathrm{mm}$ (6.8-8.7) in calicular diameter and $4.8 \mathrm{~mm}$ (4.5-6.0) in fossal depth. Each pair of S4 fused before enclosed S3, further each pair of outer S4 fused with S2 forming Duplicate Pourtalès plan, these complicate septal arrangement seems like one of cat's cradle. S5 rarely appeared as rudimentary lines. Columella consists of swirled elements though variable in shape. Septa not exert from thin wall.

\section{Etymology}

The specific name paragracilis is a combination of prefix para, meaning "side" in Latin, and the specific name of Dendrophyllia gracilis (Milne-Edwards and Haime, 1848) (=Cladopsammia gracilis: recently, Cairns (1994) transferred to the genus name) to which the new species is similar.

\section{Remarks}

This new species has similar septal arrangement to D. gracilis, though Duplicate Pourtalès plan with thin cylindrical calice distinguishes it from $D$. gracilis, which has a Triplicate Pourtalès plan (Ogawa and Takahashi, 1995) with robust trumpet or cup shape of calice. Ecologically, this species inhabits in dark caves, and the same species was obtained from the marine cave of Ryukyu Islands (Dr. Mori of Tohoku University, personal communication).

\section{Dendrophyllia futojiku n. sp.}

(Japanese name: Futojiku-kisango, new)

(Plate II, Fig. 1; Plate IV, Fig. 1)

Material examined

Holotype: Five colony fragments broken basally, consisting of 36 corallites, collected on 6 June, 1970 , by K. Takahashi at $2 \mathrm{~m}$ depth using SCUBA, at Izu Hachijou Island, Tokyo. The holotype is deposited in the National Science Museum, Tokyo (NSMT-Co 1002).

Paratype: Twelve colony fragments broken basally, consisting of 36 corallites, collected simultaneously with the holotype. It is deposited in the Takahashi collection.

Additional specimen: One colony consisting of 26 corallites collected on 9 August, 1981, by $\mathrm{K}$. Takahashi at $2 \mathrm{~m}$ depth using SCUBA, at Izu Hachijou Island. Specimens were deposited in the Takahashi collection.

Reference specimens: All Dendrophyllia specimens that are reported in our previous paper (Ogawa and Takahashi, 1995). 
Description of holotype

Corallum dendroid, sparsely branching in three dimensions. 5 broken corallites height $4.3-8.4 \mathrm{~cm}$. Corallite comparatively thick, costae very fine $0.05 \mathrm{~mm}$ width with a small spine row. Epitheca developed. Calice almost circular. Coenenchyme orange, tentacles yellow (Plate IV, Fig. 1).

Septa hexamerally arranged in complete 4 cycles. Corallite medium size, almost circular, 7 mature corallites averaging $7.2 \mathrm{~mm}$ (range: $6.1-8.0) \times 7.6 \mathrm{~mm}(6.6-8.6)$ in calicular diameter and $3.6 \mathrm{~mm}(2.5-4.0)$ in fossal depth. Each pair of S4 fused before enveloped S3 forming Simple Pourtalès plan. Columella spongy and well developed, almost circular, average maximum diameter $3.8 \mathrm{~mm}(3.3-4.5)$. Inner edges of septa vertical and straight, columella occupied about $51 \%$ of the calice area. Septa not exert from the wall.

Etymology

The specific name futojiku meaning fat or big columella in Japanese.

\title{
Remarks
}

Though columella is usually variable in size in the same colony, this new species is easily distinguished from other known Dendrophyllia by its well developed columella without exception among the colony.

\author{
Dendrophyllia minima n. sp. \\ (Japanese name: Mini-kisango, new)
}

(Plate II, Fig.2; Plate IV, Fig.2)

Material examined

Holotype: Small colony consisting of about 60 corallites collected on 24 July, 1982, by K. Takahashi at $2 \mathrm{~m}$ depth using SCUBA, at Izu Hachijou Island, Tokyo. The holotype is deposited in the National Science Museum, Tokyo (NSMT-Co 1003 ).

Paratype: Small colony consisting of 51 corallites collected on 28 September, 1980, by K. Takahashi at $2 \mathrm{~m}$ depth using SCUBA, at Izu Hachijou Island, Tokyo. It is deposited in the Takahashi collection.

Additional specimen: Small colony consisting of 20 corallites, collected at the same place for paratype. Specimens are deposited in the Takahashi collection.

Reference specimens: Dendrophyllia compressa Eguchi and Sasaki, 1973 newly collected from Izu Hachijou Island, Tokyo.

\section{Description of holotype}

Corallum very small, bush like, sparsely branching colony: height $3.0 \mathrm{~cm}$, width $3.3 \mathrm{~cm}$. Corallite thick, calice eclliptical, $10.9 \mathrm{~mm}$ (7.9-13.0) in length. Costae very fine, width less than $0.02 \mathrm{~mm}$ with a spine row. Epitheca developed. Coenenchyme orange in basal part and yellow in distal part, tentacles transparent (Plate IV, Fig 2).

Septa hexamerally arranged in complete 4 cycles. Corallite very small, 5 mature corallites averaging $4.1 \mathrm{~mm}$ (range; 3.7-4.2) $\times 4.8 \mathrm{~mm}(4.0-5.7)$ in calicular diameter, $3.6 \mathrm{~mm}(3.0-4.0)$ in fossal depth. Each pair of S4 fused before enclosed S3 forming Simple Pourtalès plan. Septa exert sharply, S1 and S2 exert $0.8-1.0 \mathrm{~mm}$, and others less than $0.5 \mathrm{~mm}$. 


\section{Etymology}

The specific name minima indicates this is the smallest colony of Dendrophyllia hitherto known.

\section{Remarks}

The compressed shape of calice is similar to $D$. compressa, though its size is very different that $D$. compressa is $5.0 \mathrm{~mm} \times 6.2 \mathrm{~mm}$ in calicular diameter and forms a big colony (Ogawa and Takahashi, 1995).

We revised our previous key (Ogawa and Takahashi, 1995) to the species of Dendrophyllia with related genera in Japan, as shown in Appendix Table.

\section{Acknowledgements}

We thank Mr. H. Tachikawa of the Chiba Central Museum for the collection, and Dr. H. Uchida of the Kushimoto Marine Park Center for loan the specimens and useful comments, Dr. Y. Shirayama of the Seto Marine Biological Laboratory, Kyoto University for useful comments, and Dr. T. Nishikawa of the Nagoya University for useful suggestions. We are also very grateful to Dr. S. D. Cairns of the Smithsonian Institution for critical reading the manuscript with valuable suggestions. This is Contribution number 32 from the Z. Nakai Laboratory.

\section{References}

Alcock, A. 1902. Report on the deep-sea Madreoporaria of the Siboga Expedition. Siboga-Expeditie, 16a, 51 pp. 5 pls.

Blainville, H. M. D. de 1830. Zoophytes. Dictionnaire des Sciences Naturelles, 60, Strasbourg, F. G. Levault, $546 \mathrm{pp}$.

Bourne, G.C. 1905. Report on the solitary corals collected by Professor Herdman, at Ceylon, in 1902. Ceylon Pearl Oyster Fisheries, Supplementary Reports, 29, 187-242. 4 pls.

Cairns, S. D. 1994. Scleractinia of the temperate North Pacific. Smithsonian Contributions to Zoology, 557,150 pp. 42 pls.

Duncan, P.M. 1876. Notice of some deep-sea and littoral corals from the Atlantic Ocean, Caribbean, Indian, New-Zealand, Persian Gulf, \& Japanese and c. Seas. Proceedings of the Zoological Society of London, 1876, 428-442. 4 pls.

Eguchi, M. 1934. Eupsammidae, a family of the so-called "Deep-sea corals". The Journal of the Geological Society of Japan, 41, 365-369. [in Japanese]

Eguchi, M. 1935. On the specific name of some Madreporarian corals. Animal and Plant, 3, 2025-2027. [in Japanese]

Eguchi, M. 1965. Scleractinia. In Okada, K., Uchida, S. and Uchida, T. (eds.), New Illustrated Encyclopedia of the Fauna of Japan 1, Hokuryukan Publishing Company, Tokyo, pp. 270-296, figs. 353-452. [in Japanese]

Eguchi, M. 1968. The hydrocorals and scleractinian corals of Sagami Bay collected by His Majesty the Emperor of Japan. Maruzen Company, Tokyo, $x v+221$ pp., 70 pls.

Eguchi, M. 1973. On some new or little known corals from Japan and Australia. Publications of the Seto Marine Biological Laboratory, 20, 81-87. 1 pl.

Gardiner, J.S. and Waugh, P. 1938. The Flabellid and Turbinolid corals. Scientific Reports of the John Murray Expedition 1933-34, 5 (7), 167 - 202. 7 pls.

Horst, C. J. Van der 1922. The Madreoporaria of the Siboga Expedition. Part 3: Eupsammidae. 
Siboga-Expeditie, 16c, 45-75, 2 pls.

Horst, C. J. Van der 1926. Madreporaria: Eupsammidae. The Transactions of the Linnaean Society of London, ser. 2, 19 (1), 43-53. 2 pls.

Milne-Edwards, H. and Haime, J. 1848. Recherches sur les Polypiers, troisiéme mémoire: Monographie des Eupsammides. Annales des Sciences Naturrelles, Zoologie, ser. 3, 10, 65-114. 1 pl.

Ogawa, K. and Takahashi, K. 1995. A revision of Japanese ahermatypic corals around the coastal region with guide to identification II. Genus Dendrophyllia. Nankiseibutu, 37, 15-33. 7 pls. [in Japanese with English summary]

Ogawa, K., Takahashi, K. and Sakai, K. 1997. Notes on Japanese ahermatypic corals-I New species and subspecies of Culicia and Phyllangia. Publications of the Seto Marine Biological Laboratory, 38, 45-52. 1 pl.

Rehberg, H. 1892. Neue und wenig bekannte Korallen. Abhandlungen aus dem Gebiete der Naturwissenschaften, $12(1), 50$ pp. 4 pls. 


\section{Appendix: Key to the 20 species of Dendrophyllia and related genera in Japan}

1. Colony like small, low tree; main trunk of even diameter, with sparse branching or budding ${ }^{*}{ }^{1} \ldots . . .2$ Colony bushy or grass-like, main trunk obscure; branches bifurcating or irregularly budding like a

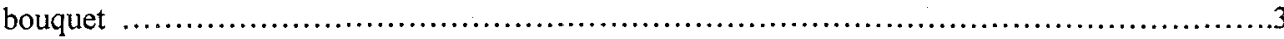
Colony growing upright like big tree with main trunk; extensive branching or budding from main trunk ..................................................................................... Colony plocoid with no trunk, coenosteum developed between corallites, latter almost submerged to highly exert, budding fundamentally bifurcating ${ }^{2}$........................................11

2. Fossa shallower than $4 \mathrm{~mm}$.....................Eguchipsammia fistula (Alcock, 1902) Hoso-kisango Fossa deeper than $6 \mathrm{~mm}$

Dendrophyllia praecipua (Gardiner and Waugh, 1938) Minami-hoso-kisango

3. Colony and calices smallest, $5 \mathrm{~mm}$, of all species .................. . minima $\mathrm{n}$. sp. Mini-kisango Calices biggest, $20 \mathrm{~mm}$, of all species ................... japonica Rehberg, 1892 Nihon-kisango Calice considerably compressed ............ . compressa Eguchi and Sasaki, $1973^{* 3}$ Henpei-kisango

4. Main trunk standing almost straight upright, even in diameter .................................

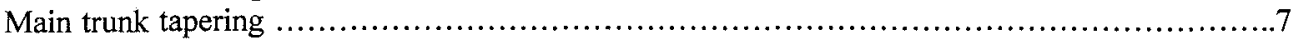

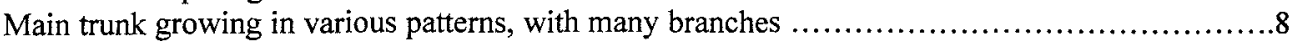

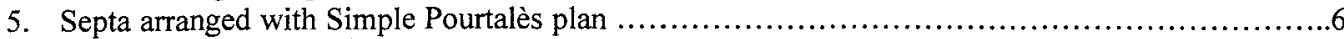
Septa arranged with Duplicate Pourtalès plan .....................D. paragracilis n. sp. Ayatori-kisango Septa arranged with Triplicate Pourtalès plan ...............D. suprarbuscula $\mathrm{n}$.sp. Naga-juji-kisango

6. Columella occupies almost entire calice ........................... f. futojiku $\mathrm{n}$. sp. Futojiku-kisango Columella normal-sized, branches short........................D. arbuscula Horst, 1922 Juji-kisango Columella normal-sized, branches long .........D. cylindrica Yabe and Eguchi, $1968^{* 4}$ Entou-kisango

7. Septa arrnaged with complete Pourtalès plan ............... ijimai Yabe and Eguchi, $1968^{* 5}$ Kisango Septa arrnaged with incomplete Pourtalès plan ........... D. minuscula Bourne, 1905 Koeda-kisango

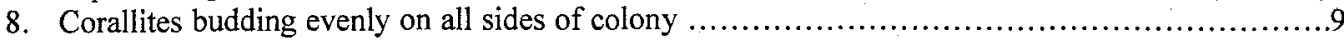
Corallites budding on only one side of colony, colony pseudo-bifacial

D. cyathohelioides Yabe and Eguchi, $1968^{*}$ Okinose-kisango

Corallites budding alternately from trunk and directed obliquely upwards

...10

9. Corallites almost embedded in trunk; almost septa arranged pentamerally

Corallites with long trunk; septa arranged hexamerally without exception.

D. subcornigera Yabe and Eguchi, $1968^{* 4}$ Enoura-kisango

10. Corallum robust, calice rather thick and compressed...... D. boschmai Horst, 1926 Boshuma-kisango Corallum thin and slender ......................... cf. florulenta Alcock, $1902^{* 6}$ Hanagata-kisango

11. Branches short, calice shaped like short trumpet .... Cladopsammia gracilis (Milne-Edward and Haime, 1848) Nagaibo-kisango Branches long, calice shaped like long trumpet .........C. coccinea (Ehrenberg, 1834) Ooeda-kisango No branches, calices almost embedded in coenosteum ...C. coarctata (Duncan, 1876) Ooibo-kisango

${ }^{* 1}$ Cairns (1994) transferred unattached species to Eguchipsammia from Dendrophyllia

${ }^{*}$ Cairns (1994) transferred this group to Cladopsammia from Dendrophyllia

${ }^{* 3}$ Eguchi (1973) designated author name as Eguchi and Sasaki

${ }^{*}$ Eguchi (1934) cited this specific name with author Yabe and Eguchi without description, there are no descriptional paper until Eguchi (1968)

${ }^{* 5}$ Eguchi (1935) cited this specific name without description, and author name Yabe et Eguchi found in Eguchi (1965) with description in Japanese, there are no descriptional paper in English until Eguchi (1968)

${ }^{* 6}$ Not obtained, based on the description of Eguchi (1968) 


\section{Explanation of Plates}

\section{Plate I}

Fig. 1. Dendrophyllia suprarbuscula n. sp.

1a: Enlarged calice $(\times 2.3), 1$ b: Enlarged costae $(\times 2.6)$

Fig. 2. Dendrophyllia paragracilis $\mathrm{n}$. $\mathrm{sp}$.

2a: Enlarged calice $(\times 2.5), 2 \mathrm{~b}$ : Enlarged costae $(\times 3.5)$

Scales graduated in $\mathrm{mm}$.

\section{Plate II}

Fig. 1. Dendrophyllia futojiku n. sp.

1a: Enlarged calice $(\times 2.8), 1$ b: Enlarged costae $(\times 2.9)$

Fig. 2. Dendrophyllia minima n. sp.

2a: Enlarged calice $(\times 3.0), 2 \mathrm{~b}$ : Enlarged costae $(\times 3.5)$

Scales graduated in $\mathrm{mm}$.

\section{Plate III}

Fig. 1. Dendrophyllia suprarbuscula $\mathrm{n}$. sp.

Fig. 2. Dendrophyllia paragracilis $\mathrm{n}$. $\mathrm{sp}$.

\section{Plate IV}

Fig. 1. Dendrophyllia futojiku n. sp.

Fig. 2. Dendrophyllia minima n. sp. 
Publ. Seto Mar. Biol. Lab., 39(1), 2000

Plate I

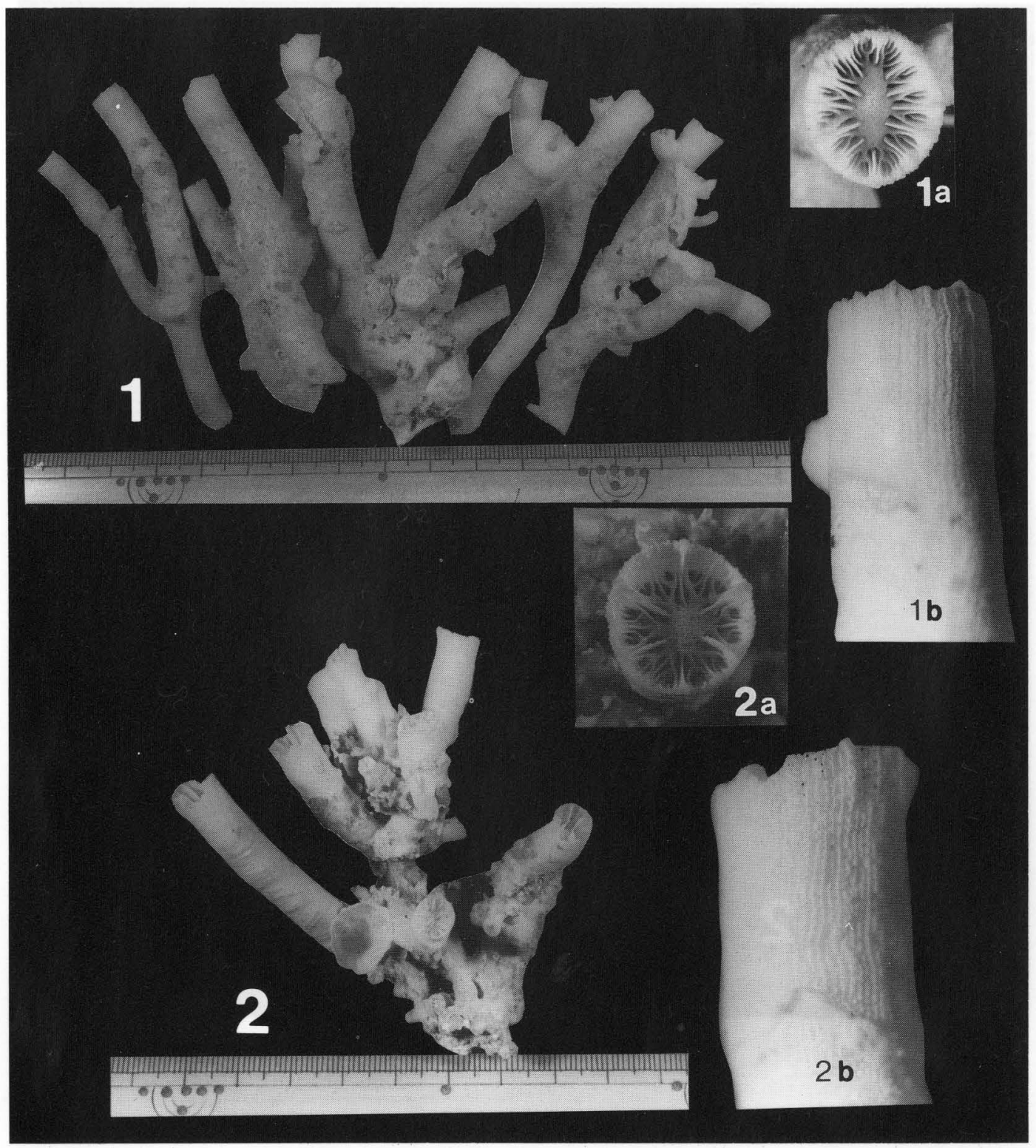




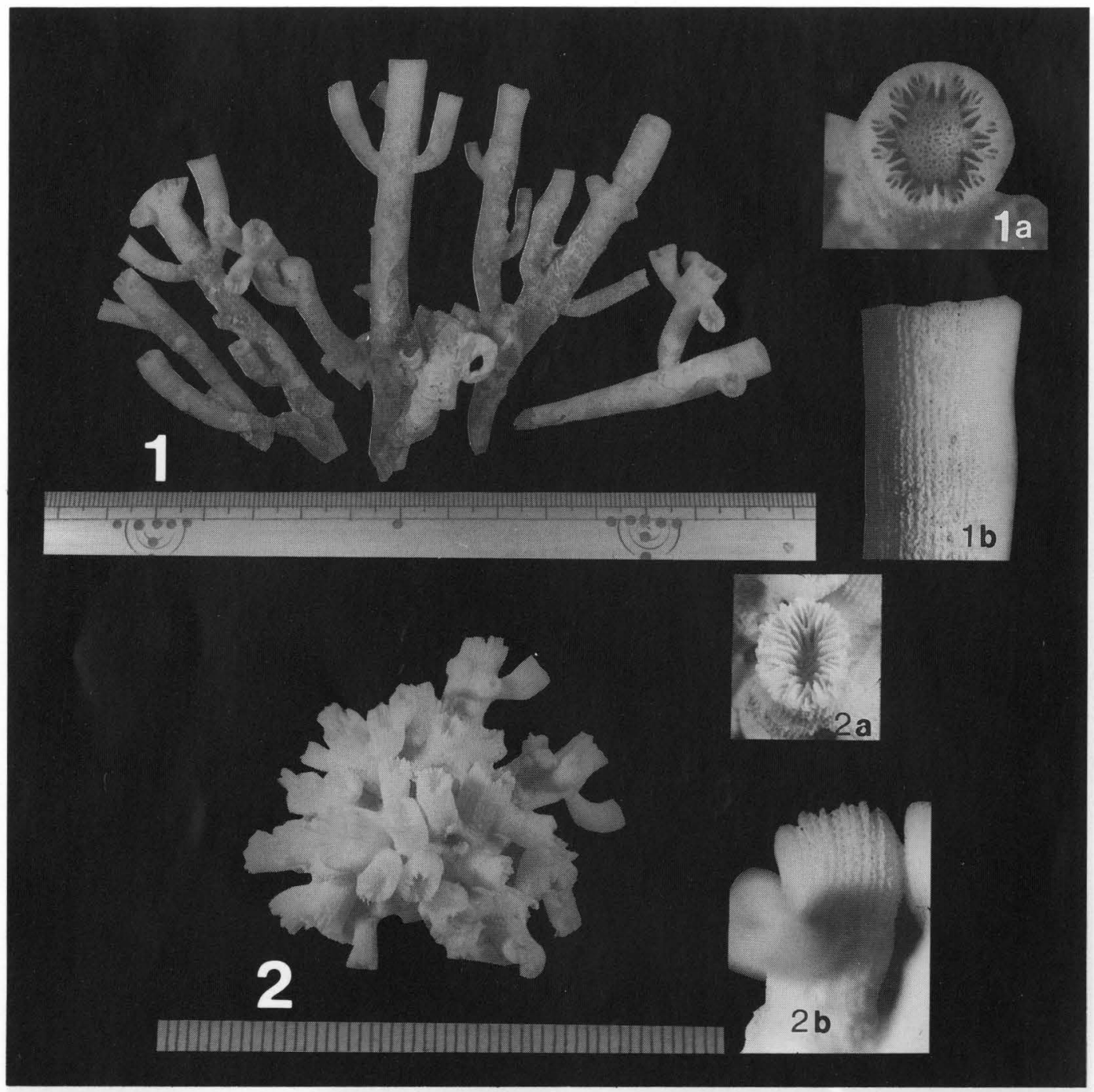


Publ. Seto Mar. Biol. Lab., 39(1), 2000

Plate III

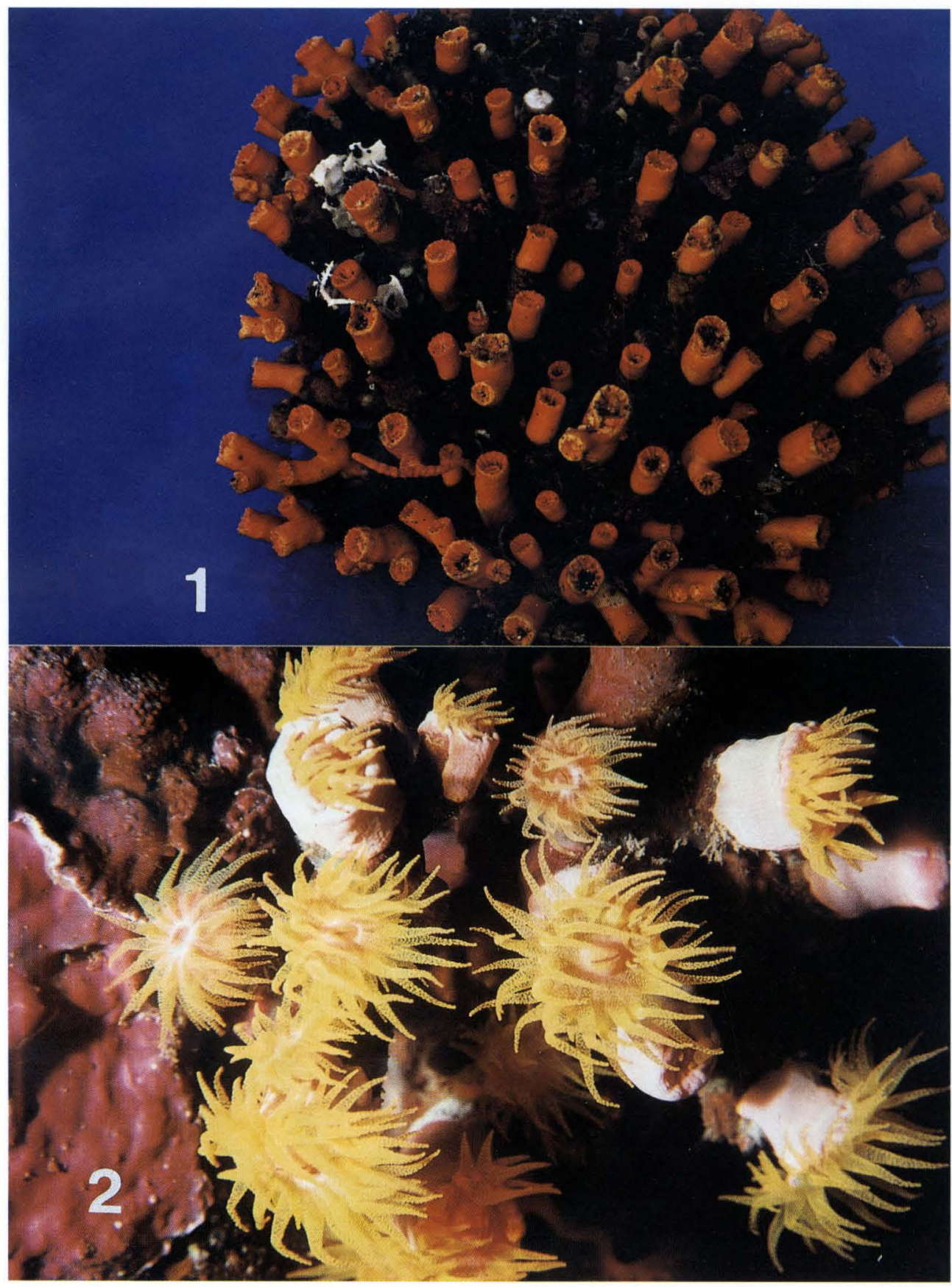


Publ. Seto Mar. Biol. Lab., 39(1), 2000

Plate IV

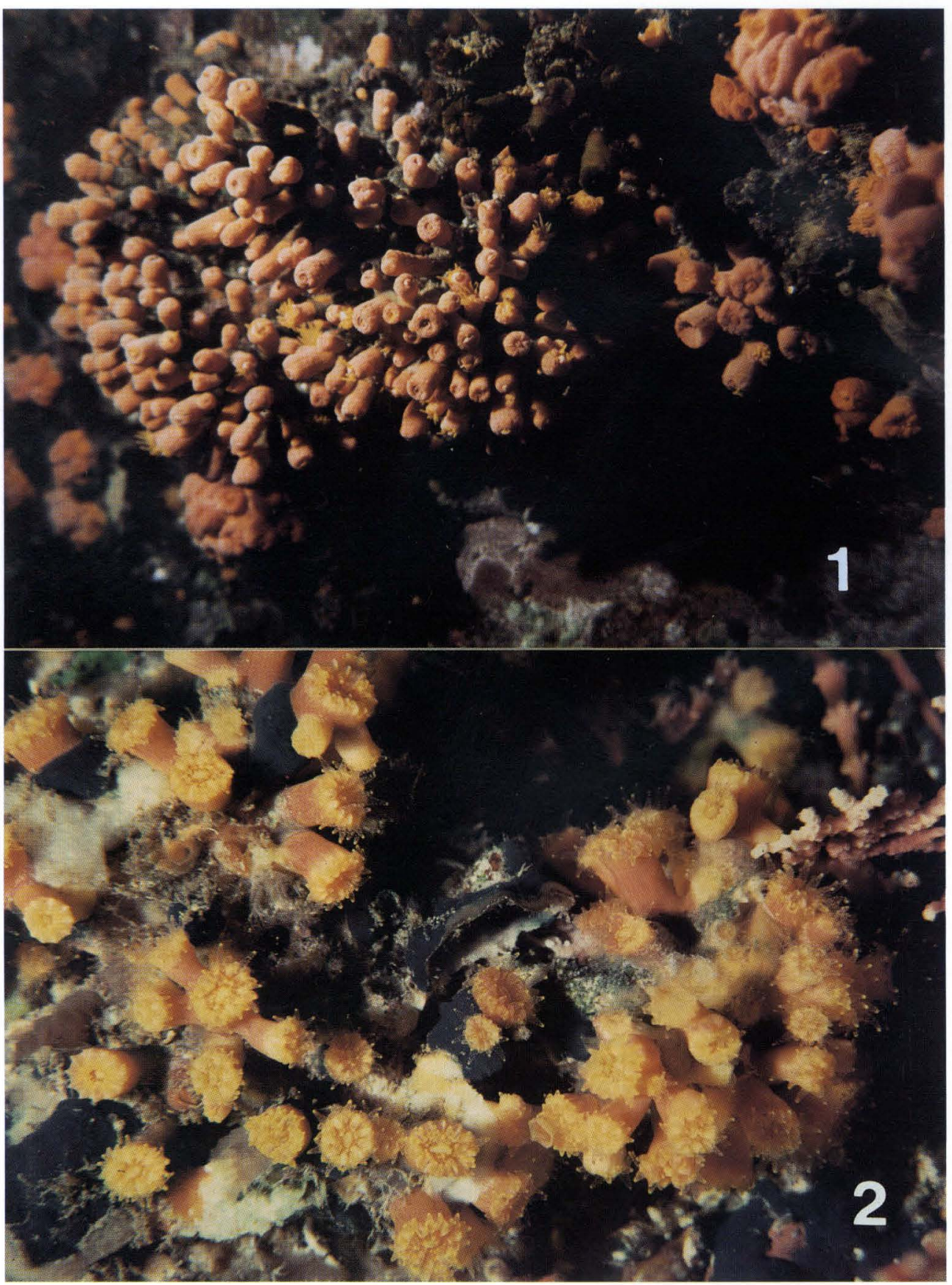

